
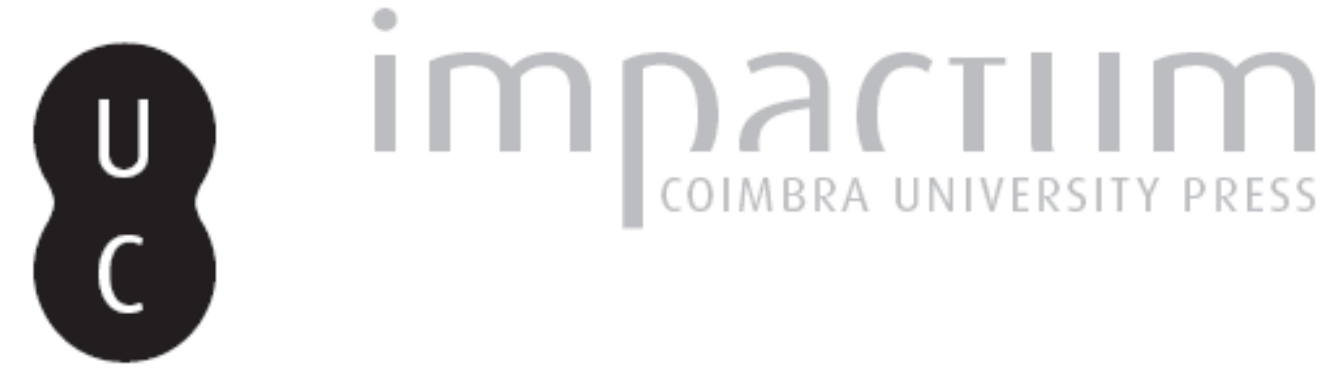

A Portuguese poem for Europe (1945): the European ideal of Adolfo Casais Monteiro Autor(es): Baltazar, Isabel Publicado por: Centro de Informação Europe Direct de Aveiro; Centro de Estudos

URL persistente:

DOI: DOl:http://dx.doi.org/10.14195/1647-6336_13_3

Accessed : $\quad$ 26-Apr-2023 12:58:09

A navegação consulta e descarregamento dos títulos inseridos nas Bibliotecas Digitais UC Digitalis, UC Pombalina e UC Impactum, pressupõem a aceitação plena e sem reservas dos Termos e Condições de Uso destas Bibliotecas Digitais, disponíveis em https://digitalis.uc.pt/pt-pt/termos.

Conforme exposto nos referidos Termos e Condições de Uso, o descarregamento de títulos de acesso restrito requer uma licença válida de autorização devendo o utilizador aceder ao(s) documento(s) a partir de um endereço de IP da instituição detentora da supramencionada licença.

Ao utilizador é apenas permitido o descarregamento para uso pessoal, pelo que o emprego do(s) título(s) descarregado(s) para outro fim, designadamente comercial, carece de autorização do respetivo autor ou editor da obra.

Na medida em que todas as obras da UC Digitalis se encontram protegidas pelo Código do Direito de Autor e Direitos Conexos e demais legislação aplicável, toda a cópia, parcial ou total, deste documento, nos casos em que é legalmente admitida, deverá conter ou fazer-se acompanhar por este aviso.

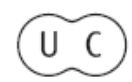


DEBATER

A EUROPA

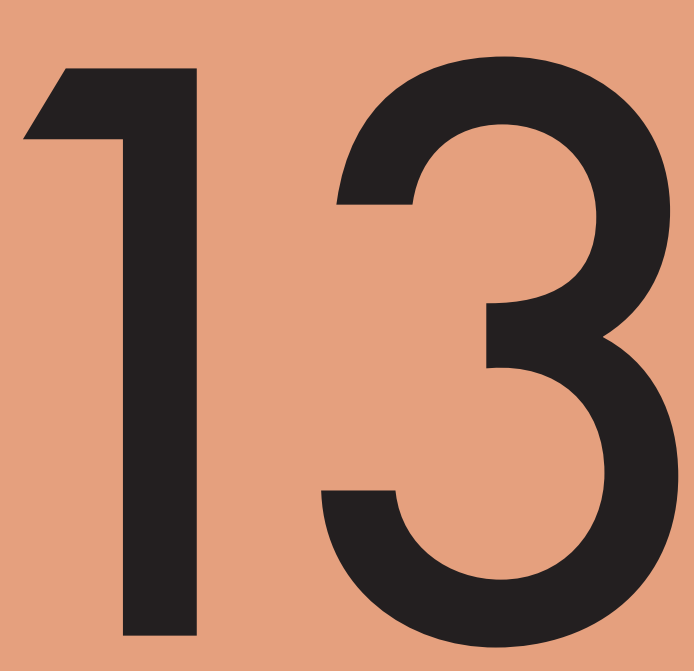

jul-dez 2015
A (DES) CONSTRUÇÃO DA EUROPA
(1939-1945)
(DE) CONSTRUCTING EUROPE (1939-1945) 


\title{
A Portuguese poem for Europe (1945). The European ideal of Adolfo Casais Monteiro
}

Isabel Baltazar

Fellow Research at the Interdisciplinary Research Centre of the twentieth century

University of Coimbra - CEIS20

E-mail: ibaltazar@fcsh.unl.pt

\begin{abstract}
As part of this work, we only restrict this analysis to the period immediately before the war, i.e. from 1939, when she prepares to start. We wish to show that the European Union projects, presented with great breath in previous decades as a result of the first world war, were not merely circumstantial. Before the world war still exist these ideas to unite Europe, achieved through the presentation of specific proposals, presented at various levels, not being "utopias" of intellectuals or even isolated politicians who dream of a "Europe whole and free".In the twenty-first century, Europe is still an unfinished work, a "dream unfulfilled." Despite sixty years of European construction, and the actual achievements made, the European project, announced soon after the First World War, and implemented by the "method of small steps" after the second conflict, still remains valid. Europe is still Europe, future dream, as prophetically announced Adolfo Casais Monteiro.
\end{abstract}

Keywords: Europe; Second War; European Construction; Portugal; European Ideal

\section{The idea of European unity before the second great war}

As part of this work, we only restrict this analysis to the period immediately before the war, i.e. from 1939, when she prepares to start. At that time, will be advocated a Federal Europe by Leo Blum, and, two years later, is drawn up the 
Ventotene Manifesto ${ }^{1}$, which calls for precisely the Union of efforts towards a free and United Europe. When choosing treat this event and those who followed, we wish to show that the European Union projects, presented with great breath in previous decades as a result of the first world war, were not merely circumstantial. Before the world war still exist these ideas to unite Europe, achieved through the presentation of specific proposals, presented at various levels, not being "utopias" of intellectuals or even isolated politicians who dream of a "Europe whole and free". Fit a political context motivated by State represented in wills dating marked for that purpose. That's why, in our view, a loss of overall view of look that European unity by jumping the famous Plan Briand for return to find the idea of European unity in the postwar period, again, as in the interwar era, for reasons of necessity. Don't. European unity is not only a result of does not exist another way possible to rebuild Europe. The European Union has been existing as a project, even, and despite, interstate conflict, showing that even a veiled idea, or seeming to be, not erased fully the "spirits" of Nations that, in spite of political differences or Imperial desires, continue to realize the need to unite Europe.

It seemed that the idea of European unity had to be suspended with the rise of dictatorships. At first glance, it would be the logical consequence of a totalitarian power, for whom the use of force would make sense in order to achieve the purposes determined by the desire to build Empires. Everything was opposed to the ideas of peace and freedom. However, there was also an idea of European unity, attained by force and, therefore, a European-ness, taken to the last consequences. Some, like Hitler, conceive this Union by force ${ }^{2}$, but others, motivated by more and greater reasons, conceive a United Europe for freedom and desire of Nations.

\section{A European-ness of resistance: the Manifesto of Ventotene (August 1941) for a free and United Europe}

\footnotetext{
${ }^{1}$ This manifesto will be discussed in detail in the following section.

2 The idea of a unified Europe was also part of Nazi propaganda. In May 1941, Hitler goes so far as to declare: "This is not a war like other wars, it's a revolution where new a Europe will emerge, reorganized, prosperous", coming to add two years after "all the clutter of small states that still exist in Europe should be settled as quickly as possible. The aim of our struggle must be to create a unified Europe. Only the Germans can really organize Europe ". Quoted by Gérard Soulier, A Europa. História, Civilização Instituições, Lisbon, Instituto Piaget, 1997, p.258.
} 
At the same time, a European-ness of resistance was developed which attempts to continue the previous projects for Europe, opposites in everything to the political reality experienced and "dreamed" in exile. As has already been mentioned, as early as 1939, Leo Blum would write an article in the newspaper Le Populaire defending a Federal Europe: "The solutions in which we, Socialists, think are those that would translate the integration of Germany into a European Organization that would provide solid guarantees against the return of attacks by force, providing the elements of a true security and lasting peace. Thus, we return to the same formulas, always to the same conclusion: the independence of Nations within a federal and disarmed Europe. These are our war objectives, which means that, for us, these are the conditions of peace " 3 .

Others wanted to keep the idea of federalism, presented at various levels during the period between-the-wars, especially in France, Belgium, Italy and the Netherlands. There were two Italians who excelled, when deprived of liberty, they don't get stuck on the ideas, for which they will keep alive their European-ness. Thus, alongside fascism an anti-fascism develops and a United Europe by Force to a United Europe for freedom. This was the message of the Ventotene Manifesto. Conceived at the place which gave it the name, situated in Lipari Islands, by two figures antifascists - Altiero Spinelli ${ }^{4}$ and Ernesto Rossi ${ }^{5}$ - this would be the program of a European movement-European federalist movement - founded clandestinely by those figures in June $1941^{6}$. Considered by many ${ }^{7}$ to be the Bible of European unity, the Ventotene manifesto sets out the principles which will be subsequently followed by the federalist movements. It's the beginning of an outline of the new Europe, a Europe against the war, and therefore a Europe, almost, without borders or in which boundaries are not cause for war. A Europe that gives new life to the old continent by the Union of its reconciled people, and thus will have a new face to the world. For this to happen it is necessary to solve problems:

\footnotetext{
${ }^{3}$ Cited by Dusan Sidjanski, O Futuro Federalista da Europa, Lisbon, Gradiva, 1996, p.20

${ }^{4}$ Altiero Spinelli (1907-1986) - born in Italy, communist prisoner thirteen years (1927-1943). Contrarian of the Moscow process in the thirties of PCI and adheres to the liberal socialists. Founder of the European Federalist Movement, being its general secretary from 1948 to 1962. In 1968-1969 was adviser to P. Nemmi and later member of the European Communities and Member of the European Parliament.

${ }^{5}$ Ernesto Rossi (1897-1967) - Writer and Professor of Economics, founded a socialist liberal and antifascist movement. Prisoner from 1930 to 1943 and founder of the Italian radical movement in the fifties.

${ }^{6}$ It is noteworthy that this movement will leave the clandestinity when, after the fall of Mussolini, it creates a European Federalist Movement, from Milan (August 1943). This will defend the ideas of federalism, most notably the European Citizenship.

${ }^{7}$ Cfr. Pierre Gerbet, "L'idée européenne dans la Résistence et chez les Alliés" in La Construction de l' Europe, Paris, Imprimerie Nationale, 1983, pp.48-54.
} 
"The problem that we solve first- under the consequence of making any other eventual progress in vain is the definitive abolition of the division of Europe in sovereign national States. The collapse of most of the States of the continent under the German compressor cylinder already unified the destiny of the peoples of Europe, called upon to submit jointly to the Hitlerian domain or suffer together and evenly, after the fall of that, a revolutionary crisis face to which there won't be presented condensed and distinct in solid state structures. The spirits are already more open than in the past, in regards to a reorganization of the federal-type Europe. The harsh experience of these last decades, opened eyes to those who do not want to see and matured many elements favourable to our ideal. All reasonable men admit from now that it is as impossible to maintain a balance between European States, among which the militaristic Germany would benefit from the same conditions as other countries, as is to shred Germany and keep it chained up, once won over. It is, moreover, proved that no country in Europe can stay in its corner while others are fighting, not having the declarations of neutrality and non-aggression pacts any value. Henceforth, the worthlessness was demonstrated-and even the harmfulnessof bodies like the United Nations that intends to ensure international law, without an international force able to impose its decisions and not respect, besides, the absolute sovereignty of the Member States "8.

As we read, its fundamental aspect relates to the finding of the crisis of the nationState, defending the route of federalism by creating "a European Federation which have been transferred sovereign powers relating to interests common to all Europeans" ${ }^{9}$. If the first was responsible for European rivalries, the second would lead to the United States of Europe:

"For the propaganda and the action, seeking to establish, in every possible way, agreements and alliances between the various movements which, in different countries, inevitably form, it is necessary to post, as of now, the foundations of a movement capable of mobilizing all forces and which can generate the new organism that will be the grandest and most innovative creation achieved in Europe for centuries: this in order to constitute a solid federal State which has a European armed force - in replacement of national armies - which breaks with the decidedly economic autarkies, backbone of totalitarian regimes, which possesses organs and sufficient means to perform, in the different Federal States, their own deliberations with a view to maintaining a common order said the States, leaving to those Federal States, the necessary

\footnotetext{
${ }^{8}$ Extract of the Ventotene Manifest. Cited by Marc Nouschi, Em busca da Europa, Lisbon, Piaget, 1996, p.64-65.

Ventotene Manifest. The full version that is found on the internet: http: //www..romanaacivica.net/anpiroma/antifascismo/antifascismo4a.html. It consists of a clear text in the original Italian language and has 18 pages.
} 
autonomy for a flexible articulation and for the development of a policy in accordance with the particular characteristics of the different peoples"10

Moreover, the text calls on the European citizenship, in which the inhabitants of the States exercising their power to choose and control the Federal Government, submitting directly to its laws. Finally, the text argues for the existence of a European Constitution to be drawn up by a European Assembly and ratified by the national parliaments.

The year of 1941 would be rich for the European-ness of resistance. Also in France it was alive and kicking, proclaiming, even, the United States of Europe. This idea, supported by many, was conveyed by the press, most notably, the journal whose name well characterizes the euro-enthusiasm: Combat ${ }^{11}$. In it many figures will collaborate such as Georges Bidault, Pierre-Henri Teitgen, Edmond Michelet, François de Menthon or Albert Camus. The latter would write about the need for peace in Europe and throughout the world, impossible without a peaceful Germany:

"Whatever our inner passion and memory of our revolt, we know well that peace in the world needs a peaceful Germany, and that a country cannot be pacified when is excluded forever from the concert of Nations. If the dialogue with Germany is still possible, the reason requires that we accept. "12

Convinced that the United States of Europe will one day come true, for them they "fight" hard. Some numbers of this newspaper reveal this, in the number of September 1942, it can be read on an article by Henri Freney, that "the United States of Europe-a step toward world unity-will soon be a living reality, for which we fought ... in an organized Europe under the principles of Freedom, Equality, Fraternity ${ }^{13}$, adding the editorial of December 1943 the resistance to be" the hope of Europe, the cement of the unions of tomorrow"14. Then in 1942 the magazine L'Unita Europea, organ of divulgation of federalist ideas, would arise as well, and two years later emerges in Geneva a key text, entitled Tomorrow's Europe, reflecting the spirit of European

\footnotetext{
${ }^{10}$ ibidem

${ }^{11}$ French newspaper founded in 1941.

12 Albert Camus, Jornal Combat, 1947

${ }^{13}$ Cited by Gérard Bossuat, Les Fondateurs de l'Europe, Paris, Éditions Bélin, 1994.

14 Cited by José Adelino Maltez, Por uma Europa radicalmente europeia, in www.maltez.info, 20.04.04,p.21.
} 
resistance $^{15}$. In it were expressed the moral, social and political principles defended against Nazism, only possible if "several countries accept to overcome the dogma of the absolute sovereignty of states integrating into a single federal organization. European peace is the cornerstone of world peace. Indeed, in the space of a single generation, Europe was the epicenter of two world conflicts that were originated, primarily, by the existence on this continent of thirty sovereign states. It is necessary to remedy this anarchy by creating a Federal Union between the peoples of Europe "16.

In the same year, it was created a Study Committee by Jean Moulin, general delegate De Gaulle, in order to study the future of Europe. In it we find figures such as Paul Bastid, Robert Lacoste, Alexandre Parodi, René Courtin and Michel Debré. The Cahiers Politiques would give account on the current situation and future prospects. The first issue, from April 1943 is dedicated to "France and the European idea." The same publication in January 1944, would defend a policy that was not restricted to a vision of states separated by borders but united by an ideal, even risking saying that "one of the first accomplishments will be the creation of a United States of Europe. It is not about utopia: the United States of Europe is underway"17 ${ }^{17}$ The year of 1943 was rich in interventions in favor of Europe. It is also important to remember the role of intellectuals who, in writing or by voice, can influence public opinion. It should be highlighted the appeal to the Europeans of Thomas Mann, who, via the New York radio, talks of Europe:

"The great ideal of Europe has been perverted and corrupted so frightfully; fell into the hands of the Nazis, who, ten years ago, conquered Germany and succeeded - thanks to your disunity - to subdue the whole continent This conquest of the continent is presented by the Nazis as the unification of Europe, as the new order under the laws of history. Of all the untruths of Hitler, the most insolent is the European illusion, the perversion of the European idea (...) Know, European listeners (... ) the real Europe will be created for you, with the help of the free potencies" 18 .

\footnotetext{
${ }^{15}$ It should be noted that this Declaration of European resistance was signed by representatives from France, Italy, Germany, Norway, Denmark, Poland, Czechoslovakia and the Netherlands, countries of the Atlantic Charter.

${ }^{16}$ Cited by José Adelino Maltez, op. cit., p. 21.

${ }^{17}$ Dusan Sidjanski, op. cit., p. 21.

${ }^{18}$ Cited by Hubert Halin, L'Europe unie objectif majeur de la résistence, foreword by Paul-Henri Spaak, Paris-Bruxelas, Éditions de l'Union des résistents pour une Europe Unie(URPE), 1967, p. 47-48.
} 
It is in the very Nazi Germany where the European-ness lives; one Europeanness so much growing as the experienced repression. So in the middle of absolute secrecy the writing of Friedrich Goerdeler, head of a conspiratorial movement against Hitler, would appear which expressed his accession to the united Europe in his secret diary in March 1943: "Unification of Europe in the basis of independent European states: this unification shall occur in stages! A European economic union will be created immediately with a permanent economic council. Political unification will not precede, instead, it will follow the economic union!"19.

These words, of those who can only secretly go against the current established policy, are truly prophetic if we look at the later European course. Goerdeler would continue that project, thinking of a European Ministry of Economy, a common army and Ministry of Foreign Affairs also European. All in view of the participation of democratic Germany in that Unified Europe, once freed from the power of Hitler. This is, moreover, the feeling of the other resistances in particular in France and Italy. They all seem to realize how important the integration of Germany is to the success of peace, unity and freedom in Europe. More radical was the position of Huber who, at the University of Munich, proposed a European federalism, which would lead to the creation of the White Rose movement ${ }^{20}$.

\section{Draft declaration of the European resistance}

Other clandestine newspapers, particularly in France and the Netherlands, follow the movement of European resistance that will ultimately meet secretly in Geneva on March 31 of 1944, with the presence of militants from Denmark, France, Italy, Norway, Netherlands Poland, Czechoslovakia and Yugoslavia, plus an anti-Nazi group from Germany. This meeting would be followed by four gatherings from which would come out a draft declaration of Nazi oppression resistance, which, uniting the peoples of Europe, makes them supportive. It should be noted that this is the first organized political activity of European Federalists and the first call for coordination of the various resistance movements.

\footnotetext{
${ }^{19}$ Carl Friedrich Gordeler, Memória Secreta, March 1943, cited by Dusan Sidjanski, op. cit., p. 21

${ }^{20}$ This movement would propel in February 1943 a demonstration by students but their leaders would end up being executed.
} 
Building on the Atlantic Charter, subscribers of this manifest advocate respect for the human person, safety and social justice, which require overcoming the dogma of the absolute sovereignty of states in favor of a European federal organization. This will be the path to peace in Europe and in the world since it was in Europe where two world conflicts erupted, and, therefore, it will be the Federal Union of the Peoples of Europe' restoring peace, in particular, solving the German issue. This federal Union, safeguarding democratic institutions, will rebuild political, economic and socially the old continent. This federal government must have as attributes a government that represents the people of Europe and not their states, a common defense and a European Court to ensure implementation of the federal constitution ${ }^{21}$. Germany would fully integrate this federal government being only required to adapt to the new European order:

"As for Germany and its satellites, should participate in the economic reconstruction of regions devastated, but Germany should be helped, and if necessary forced, to turn its political and economic structure, in order to integrate into the federal union . To this should be totally disarmed and temporarily submitted to a federal control, whose main tasks will be: -Confiar Power to sincerely democratic elements that led to an unequivocal fight against Nazism; -Reconstruir A democratic state and decentralized where avoidance traces of bureaucratism and Prussian militarism;

-Require The radical destruction of the agrarian and industrial feudal system;

-Integrate Heavy industry and German chemical in the European industrial organization, so you can not be re-used for German nationalists purposes;

-impedir that education of German youth is made under the Nazis, militarists and totalitarian doctrines. ${ }^{22 "}$

It is noteworthy that this was federalist current one that most would influence the European construction, although, of course, there were many other resistant voices from communist or nationalist currents. The construction of Europe could not stop. That's the concern of figures from different political and religious currents. Both the Christian Democrats, represented by Robert Schuman, Alcide de Gasperi and Konrad Adenauer, socialists like Guy Mollet, Schumacher and Spaak, like others from the economic world, as Jean Monnet and René Meyer, join the European Party establishment concerned to lift the New Europe.

\footnotetext{
${ }^{21}$ Cf. L'Europe de Demain. Centre d'action pour la fédération européenne, Neuchâtel, Éditeurs de la Becomière, 1945.

22 ibidem, pp.73-75.
} 


\section{The Europe of Adolfo Casais Monteiro: A Portuguese dream for Europeans}

It was a Portuguese who was able to, in the twentieth century, impact, somewhat proportional to what was attained by Victor Hugo in the previous century. At least, they both believed in the United States of Europe and encouraged their implementation. Both diffused by writing, after all, a political idea. In the case of Adolfo Casais Monteiro poetry would be the preferred route. Europa would be the poem in Portuguese, also translated into English, anticipating that which, precisely, would be considered one of the preferred languages of the United Europe today. On May 23, 1945 it was then heard the poem, read on the microphones of the BBC, by the voice of António Pedro, an intellectual émigré ${ }^{23}$. We were in the aftermath of the Second World War when, two weeks before, was given the Allied victory over Nazi-Fascist Axis. In a way, it was the victory of freedom from oppression, free union of people against a union achieved by force. The Portuguese poem seemed, well, come and celebrate European unity, as dreamed of by poets, idea so widespread by the intellectuals, but, so far from being a political reality. As the "prophecy" of Hugo also Adolfo Casais Monteiro seems to anticipate the future:

Europe, future dream!

Europe, morning to come,

borders without watchdogs,

nations with his frank laughter

thrown open wide!

Europe without miseries dragging his rags,

you will come one day? will come the day

wherein renasças purified?

\footnotetext{
${ }^{23}$ It should be noted that the work in question is dedicated precisely to António Pedro, "which was at the time the voice of all the Portuguese who had not forgotten their status as Europeans and citizens of the world" (dedication). As evidenced by José Augusto-France in a later edition of this work, published on the occasion of Europalia 91,by the publisher New Renaissance, António Pedro held in Lisbon in November 1940, along with António Dacosta, an exhibition of European-themed paintings, against the nationalism characteristic of the time and, most particularly, the nationalist theme of the Portuguese World Exhibition. Poet, painter and journalist, Antonio Pedro leaves for London in January 1944, where he would be hired by the BBC. There he would be the commentator of the Portuguese section, being the representative of all European and world citizens. In the text "In Memoriam", José Augusto-France recalls how after the war, returning to Portugal, António Pedro would be arrested by the political police, accused of treason.
} 
It will be one day the common home of born

in your soil devastated?

You'll know reborn, phoenix, from the ashes

It burns well, false grandeur,

the glory that your people have dreamed

- Every man for himself wanting you all?

Europe, future dream,

if ever there-to be!

Europe never knewest

hear from the depths of time,

the voice crying out in the darkness

that thy greatness was not

only the lavish spirit beings

if the bread greedy ages!

Your greatness made her

those who never asked

the race for whom they served.

Thy glory to won

hands that shaped free

your body free of handcuffs

always a dream to achieve!

Europe, O world to create!

Europe, O dream to come

while not come down to earth

the voices that have shaped

your ideal figure,

Europe, uncreated dream,

until the day come down

your spirit on the water!

Europe without miseries dragging his rags, you will come one day? will come the day wherein renasças purified?

It will be one day the common home of born in your soil devastated?

Reborn, phoenix, from the ashes

your body divided? 
Europe, you shall come only when among nations

hatred do not have the last word,

hatred not guide the greedy hand,

hand fails breath dig the burial sound

the vaults digesting the blood of the flock

- And dead cattle, finally, in daylight,

the man who dreamed, Europe is life! "24.

This poem, read in Portuguese, through the BBC microphones in London, preferred antenna of the Democrats, would have therefore a big impact: a maximum audience, if we consider that it was broadcast on a night in the aftermath of the Great War. And so, "the strong voice and letterhead of an intellectual then émigré, António Pedro, this poem written by Adolfo Casais Monteiro, one of our most courageous poets resistant to the dictatorship, awoke in those who listened the hope that also Portugal's hour of freedom would sound in the new Europe that rose on the blood and rubble resulting from the Hitlerian totalitarian criminal adventure "25. If on the one hand it was celebrated the end of the war and the advent of a New Europe, it was feared, also, that this pacifism was not lasting. Many hatreds were still alive, although contained. Hence the euphoric and simultaneously cautious tone of the poem: "Europe, future dream! / Europe, morning to come" ${ }^{26}$ but like all dreams, lives from the uncertainty of its realization:" you will come one day? the day will come / where renasças purified? "27. If the poet believes in a united Europe, based on a common history, speaking,therefore, of a common European home, expression so repeated today, on the other hand, the same history has shown how much the traits that unite are reasons for constant disunity. So, that Europe potentially one, will only fulfil its destiny in the day it listens and follows its "soul." Europe has a spirit of unity that does not, however, correspond with its bloody history. The European body is, therefore, disconnected from its spirit, and Europe is wounded by hatreds that do not respect its identity. But there is always the hope of recovering the unity, "when hatred between nations does not have the last

\footnotetext{
${ }^{24}$ Adolfo Casais Monteiro, Europa, parte I, Lisbon, Editorial Confluência, 1946, pp. 13 to 15.

${ }^{25}$ José Augusto Seabra, Preface to the aforementioned work, p. 5.

${ }^{26}$ Adolfo Casais Monteiro, op. cit., p. 13.

${ }^{27}$ Idem, ibidem.
} 
word"28, when a New Man makes a New Europe. However, Europe lives in peace treaties that do not hide, so the hegemonic temptations that lead to wars. Adolfo Casais Monteiro has full consciousness of that. As such, he speaks constantly of blood:

"O dead civilization!

Your rotten blood, never!

Body stiff, withered,

the pit, the pit!

Your new song, this yes!

Purified,

Your name, Europe,

evil that you were, redeemed,

the good that this,

shared!

Here's the decorated corpse of speeches,

in bloom wound in pus, in disgust ...

Bedecked corpse of border wars,

fictions to serve the dream of violence,

ideal masks covering old rages ...

Go corpse adorned crimes,

the elbows without rest,

find little all the earth,

any blood that's enough them!

On the corpse dance

your gravediggers their dance.

Crows black omen

Unfortunately suck your blood.

There is more blood, more dance!

And you brought, you dancing,

the footsteps of your ballet

funeral!

But the nascerás blood,

or never, future of Europe!

${ }^{28}$ Idem, ibidem 
And hand holding you

to the brink?

Blood will be born!

And arms to defend

your tomorrow?

Blood will be born!

Blood teach

- Or New Slavery

There mourning of higher-

your fields sown

of forces and tyrants.

Blood banharás

your tormented body

and Phoenix, will live! ${ }^{29}$

But the Europe of "Nations" and without borders, created by the poet, would succeed, after all, "a Europe soon divided by the Cold War, by the Iron Curtain, by the Berlin Wall, with the Stalinist totalitarianism and Soviet concentration camps to East, where inevitably an ideological and armed empire would trod under his boot the independence and the freedom of peoples subjected to it ${ }^{\prime 30}$. Hence the warning issued by Adolfo Casais Monteiro in the previous verses, sensing the imminence of new conflicts, common to survivors of war, as is pointed out in the third part:

"In the barren glacial solitude of darkness

the dead do not veil.

In successive waves of discharges

Death claimed our brothers.

Fear round

hatred lurks.

All men are alone.

Dawn will still come?

${ }^{29}$ Adolfo Casais Monteiro, op. cit., parte II, pp. 19 to 21 .

${ }^{30}$ José Augusto Seabra, op. cit., p. 6. 
They are falling one by one in the fight without trenches,

and the night seems that there will never dawn

but every drop of blood is now revolt seed,

the revolt that will sweep the face of the earth,

the priests terror claims.

The revolt to blossom into hope

the arms and mouths that were ...

Betrayal round

death lurks.

A wind flags commotion ...

Dawn of trumpets in the distance ...

Those who did not die veil. ${ }^{31}$

The fourth part of this work would continue the litany of past torments. Adolfo Casais Monteiro traces the portrait of a time of war, this time over, but the consequences are far from over. He speaks of those who died and those who survived, the latter, physically alive but whose soul is dead of so much suffering. These can tell what they saw and what they experienced. . These are war survivors who have more reasons to want Peace. But there are others: those who have not seen but heard. Among these is the poet who, sat on the couch, accompanied the events. Far away, but close. A contemporary of the World War II, perceived how much hatred still lurked in the aftermath of the events. That a bloody Europe was not guaranteed to succeed peace:

"I speak of houses and men,

the living and the dead:

passing and not back ever again ...

Do not tell me that was mathematically predicted,

ah, do not come to me with theories!

I see the desolation and hunger,

the nameless anxieties,

the terrors marked forever the tragic faces of the victims.

And I know what I see, I know imagine only a tiny,

${ }^{31}$ Adolfo Casais Monteiro, op. cit., third part, pp. 25-26. 
an insignificant share of tragedy.

I saw it, I did not believe.

If you saw, he gave in crazy or prophet,

I gave in chief of bandits in highwayman,

- But I did not believe!

Eye men, houses and animals.

I look in amazement without limits,

and I'm speechless,

on pain of being men who made all this:

this bloody pulp that reduced the whole earth,

this mud blood and soul,

thing and being,

and I ask in anguish if there will still be some hope,

if hate even good for anything ...

Let me cry - and weep!

Tears shall prepare a at least the shame of being alive,

we sanctioned by our silence crime made institution,

and while perhaps weep judge our drama,

at times be a bit of our people's suffering,

a second will be the dead and tortured,

the crippled for life, crazy and imprisoned,

will be the rotten land both corpse,

We will be the blood of the trees,

the painful womb of looted houses,

- Yes, for a moment we will be the pain of it all ...

I do not know why I fall tears,

because I tremble and shiver runs inside me,

I who have no relatives or friends in the war,

I who am abroad before all this,

I who am in my quiet home,

I who have no war at the door,

- Because I tremble and sob?

Who cares about me, say - who cries in us?

Everything here is like a river fed to know its intricacies: the streets are streets with people and cars, 
no sirens screaming irrepressible fears,

and the misery is the same misery that had ...

And if all is equal to the old days,

despite Europe around us, bloodless and martyr,

I wonder whether we are not dreaming that we are people,

no brothers or conscience, here buried alive,

with nothing but tears see later, and one night around,

one night that never comes the dawn of the morning ... ${ }^{32}$

Between hope and uncertainty, so were the days immediately following the war. If music and the news announced peace, memory evoked life in the concentration camps, the killings committed, the imprisoned lives. Hence the distrust in the future and the nonconformity with the past:

"The music was beautiful ...

came from the radio, sweet, gentle,

soft as a warm body woman ...

It was sweet, affectionate and languid ...

But I still had in his ears,

as a cry of millions of mouths:

In the concentration camp now occupied by our troops

the Germans burned thousands of living in a crematorium ...

In the huts, the dead mingled with the dying ...

The SS sergeant could not remember how many men had died ...

The dead rot in droves, and the living pluck them clothes

for the fires which side to heat up ...

In many corpses he met a longitudinal section:

They were living who had taken the dead liver and kidneys to eat-

The only meat that was left of the corpses ...

And I remember suddenly in a very old movie

where the criminal wondered:

De quoi est fait un homme, Monsieur le Commissaire?

and in their eyes I read the dread

who saw an abyss and you do not know the background ...

\footnotetext{
${ }^{32}$ Idem, ibidem, fourth part, pp. 29-31.
} 
De quoi est fait un homme? That men are made

who burned men alive? which had hundreds

Children

starving and terrified, slaves as parents?

that killed or left to die men by the millions,

that made them descend to the depths of degradation,

tortured, starved, made sore and skeleton?

It was those same men

they did little freedom,

who came to save the world from disorder,

who came to teach ORDER the planet!

Yes, that brought peace to the bars of prisons,

order with torture chambers ...

And then the music comes, caiciosa and slow,

judging erasing the shame that launched on

land!

Judging will forget the abjection of those who dreamed

clear the land of the free man insubordination!

No - not prisons or deportation or reprisals,

or torture

never end up with the free man insubordination,

free man in chains, singing in the torture,

because he sees before him the brothers who are fighting,

who are to fall for others always rise up,

crying with ever new voices

THE MAN NOT THERE - SUBMITTING TO

VIOLENCE! "33

This poem was also a call to brotherhood of Europe's United Peoples. United for freedom, long awaited in the resistance, and designed to one day be lived in a political system opposed to totalitarianism, fascism or any form of authoritarianism, only in a democratic society would be, then, possible a true union of peoples, the latter based on the values peace, solidarity and respect for Human Rights. These were to be the true values advocated by the policy. A policy based on a true life in the city seeking thus to serve its citizens, regardless of the parties that can divide them; more important than any

\footnotetext{
${ }^{33}$ Idem, ibidem, fifth part, pp. 35-37.
} 
partisan quarrels is the United Peoples Union of Europe:

"Men without party and all parties,

born with the revolt because of them not worth

nothing live to be slaves,

non-party men and all parties - less

As many as

only know how to say ORDER! and claim VIOLENCE!

those who ask blood because they are bloodthirsty, yes,

but all who have never known want anything,

those who can not say that torture political prisoners

those who can not believe

because they want to not be bothered by the pestilence

crimes committed for them

- For them to continue to believe that no ORDER

It is just gag

about free mouths are to scream until the end of time

THAT ONLY THE FREE MAN IS TO BE DECENT MAN! ". ${ }^{34}$

Once again, the poet would appeal to the union of free men who, because they finally live free, can be truly Men. Their common home, Europe, will one day be, hopes Casais Monteiro, free of all wars and divisions. It is with this cry of hope that ends, as we have seen, the poem. It should be noted that Europe's Future, suggested by the poet is also a Europe open to universality and hence the insistence of the expression "Europe, O world to create." We believe not to betray his thoughts if, in addition to a united Europe, we contemplate a United World and thus in the manner of Victor Hugo, the United States of Europe would be a first step of a United States of the World. In the twenty-first century, Europe is still an unfinished work, a "dream unfulfilled." Despite sixty years of European construction, and the actual achievements made, the European project, announced soon after the First World War, and implemented by the "method of small" steps after the second conflict, still remains valid. Europe is still Europe, future dream, as prophetically announced Adolfo Casais Monteiro:

"Europe, O dream to come

while not come down to earth

${ }^{34}$ Idem, ibidem, fifth part, pp. 35-38. 
the voices that have shaped

your ideal figure,

Europe, uncreated dream,

until the day come down

your spirit on the water!

(...)

Europe, you shall come only when among nations

hatred do not have the last word,

hatred not guide the greedy hand,

hand fails breath dig the burial sound

the vaults digesting the blood of the flock

- And dead cattle, finally, in daylight,

the man who dreamed, Europe is life! " 35 .

\section{Final Thoughts}

In the past as in the present, Europe has lived also of the contribution of the Portuguese, and, Portugal, specifically represented by Lisbon, gives identity to important landmarks of European integration. Although, at another level, not political, in the sphere of thought, particularly of political ideas, Portugal always showed a willingness to "feed" the European dream. The most paradigmatic case would happen immediately after World War II, still in its aftermath, when days before was consummated the Allied victory over the Nazi-Fascist Axis. It would be a Portuguese to be able to, in the twentieth century, impact, somewhat proportional to that attained by Victor Hugo in the previous century. At least, they both believed in the United States of Europe and encouraged their implementation. Both diffused by writing, after all, a political idea. In the case of Adolfo Casais Monteiro poetry would be the preferred route. Europa would be the poem in Portuguese, also translated into English, anticipating that which would, precisely, be considered one of the preferred languages of the United Europe today. This poem, read in Portuguese, through the BBC microphones in London, preferred antenna of the Democrats, would have therefore a big impact: a maximum audience, if we consider that it was broadcast on a night in the

${ }^{35}$ Adolfo Casais Monteiro, Europa, Porto, Confluência, 1991. 
aftermath of the Great War. And so, "the strong voice and letterhead of an intellectual then émigré, António Pedro, this poem written by Adolfo Casais Monteiro, one of our most courageous poets resistant to the dictatorship, awoke in those who listened the hope that also Portugal's hour of freedom would sound in the new Europe that rose on the blood and rubble resulting from the Hitlerian totalitarian criminal adventure "36. If on the one hand it was celebrated the end of the war and the advent of a New Europe, it was feared, also, that this pacifism was not lasting. Many hatreds were still alive, although contained. Hence the euphoric and simultaneously cautious tone of the poem: "Europe, future dream! / Europe, morning to come" ${ }^{37}$ but like all dreams, lives from the uncertainty of its realization:" you will come one day? the day will come / where renasças purified? "38. If the poet believes in a united Europe, based on a common history, speaking ,therefore, of a common European home, expression so repeated today, on the other hand, the same history has shown how much the traits that unite are reasons for constant disunity. So, that Europe potentially one, will only fulfill its destiny in the day it listens and follows its "soul." Europe has a spirit of unity that does not, however, correspond with its bloody history. The European body is, therefore, disconnected from its spirit, and Europe is wounded by hatreds that do not respect its identity. But there is always the hope of recovering the unity, "when hatred between nations does not have the last word" ${ }^{39}$, when a New Man makes a New Europe. However, Europe lives in peace treaties that do not hide, so the hegemonic temptations that lead to wars. Adolfo Casais Monteiro has full consciousness of that.

But the Europe of "Nations" and without borders, created by the poet, would succeed, after all, "a Europe soon divided by the Cold War, by the Iron Curtain, by the Berlin Wall, with the Stalinist totalitarianism and Soviet concentration camps to East, where inevitably an ideological and armed empire would trod under his boot the independence and the freedom of peoples subjected to it ${ }^{\circ 40}$. Hence the warning issued by Adolfo Casais Monteiro in the previous verses, sensing the imminence of new conflicts, common to survivors of war.

\footnotetext{
${ }^{36}$ José Augusto Seabra, Preface to the aforementioned work, p. 5.

${ }^{37}$ Adolfo Casais Monteiro, op. cit., p. 13.

${ }^{38}$ Idem, ibidem.

${ }^{39}$ Idem, ibidem

${ }^{40}$ José Augusto Seabra, op. cit., p. 6.
} 
This poem was also a call to brotherhood of Europe's United Peoples. United for freedom, long awaited in the resistance, and designed to one day be lived in a political system opposed to totalitarianism, fascism or any form of authoritarianism, only in a democratic society would be, then, possible a true union of peoples, the latter based on the values peace, solidarity and respect for Human Rights. These were to be the true values advocated by the policy. A policy based on a true life in the city seeking thus to serve its citizens, regardless of the parties that can divide them; more important than any partisan quarrels is the United Peoples Union of Europe:

\author{
"Men without party and all parties, \\ born with the revolt because of them not worth \\ nothing live to be slaves, \\ non-party men and all parties - less \\ As many as \\ only know how to say ORDER! and claim VIOLENCE! \\ those who ask blood because they are bloodthirsty, yes, \\ but all who have never known want anything, \\ those who can not say that torture political prisoners \\ those who can not believe \\ because they want to not be bothered by the pestilence \\ crimes committed for them \\ - For them to continue to believe that no ORDER \\ It is just gag \\ about free mouths are to scream until the end of time \\ THAT ONLY THE FREE MAN IS TO BE DECENT MAN! "41.
}

Democracies would rebuild themselves, healing their scars, but leaving bleeding dictatorships that had supported the Axis, as did Salazar's and Franco's. Casais questioned the fragile epitome of a catastrophe, in a call to brotherhood, in a lucid prevention directed to European democracies that gradually realize the need to redo their unity starting from the values and principles that the Nazi-fascism and Stalinism resistant fought for: freedom, human rights, social solidarity. From this awareness emerged the Communities, under the inspiration of Jean Monnet. The expectant clairvoyance of this Europe from the Portuguese intellectuals, Camões Fernando

\footnotetext{
${ }^{41}$ Idem, ibidem, fifth part, pp. 35-38.
} 
Pessoa, is a "whole Europe" in which Portugal is the "face" and the "sphinxic look ". Adolfo Casais Monteiro calls upon it in the condition of European and world citizen, in a poem that will become an emblem of Portugal in Europe. It should be noted that Europe's Future, suggested by the poet is also a Europe open to universality and hence the insistence of the expression "Europe, O world to create". In the twenty-first century, Europe is still an unfinished work, a "dream unfulfilled." Despite sixty years of European construction, and the actual achievements made, the European project, announced soon after the First World War, and implemented by the "method of small" steps after the second conflict, still remains valid. Europe is still Europe, future dream.

\section{Bibliography}

BOSSUAT, Gérard - Les Fondateurs de l'Europe, Paris, Éditions Bélin, 1994, 384 p. ISBN 9782701129624

GERBET, Pierre - "L'idée européenne dans la Résistence et chez les Alliés" in La Construction de l' Europe, Paris, Imprimerie Nationale, 1983, 498 p.

HALIN, Hubert, - L'Europe unie objectif majeur de la résistence, foreword by PaulHenri Spaak, Paris-Bruxelas, Éditions de l'Union des résistents pour une Europe Unie(URPE), 1967, 58 p.

NOUSCHI, Marc - Em busca da Europa, Lisbon, Piaget, 1996, 274 p.

MONTEIRO, Adolfo Casais - Europa, Porto, Confluência, 1991, 163 p.

SEABRA, José Augusto, Cultura Política ou a cidade e os labirintos, Lisboa, Vega, $173 p$.

SIDJANSKY, Dusan - O Futuro Federalista da Europa, Lisbon, Gradiva, 1996, 361p. ISBN 972-662-417-7. 
SOULIER,Gérard - A Europa. História, Civilização Instituições, Lisbon, Instituto Piaget,1997, 463 p. 